\title{
Fake News in Nigeria: Causes, Effects and Management
}

\author{
Ogbette, Afamefuna Samuel ${ }^{1}$, Idam, Macben Otu ${ }^{1}$, Kareem, Akeem Olumide ${ }^{1}$ \& Ogbette, Daniel Nonso ${ }^{2}$ \\ 1. Department of Public Administration and Local Government, University of Nigeria, Nsukka, Enugu \\ State \\ 2. Department of Microbiology, University of Nigeria, Nsukka, Enugu State
}

\begin{abstract}
This study examined the impact of Fake News in Nigeria: Causes, Effects and its Management in Nigeria and the world at large. Fake news in a layman understanding is said to be information fabricated without a source or element of originality. Most time, it creates tension, killings and pandemonium which are not good for the peace and unity of Nigeria and the world at large. The source of information for this study came from secondary source. From the study, we observed that the major causes of fake news are; quest for relevance, hostile government and civil actors, poor regularization / of the internet and money making. The effect of it has been so bad most especially now Nigeria is facing different intra crises like Fulani-Herdsmen and Farmers, Militancy, and so on which goes a long way to create tension, killings and pandemonium just like stated above. As a result of the above, we recommend the following: There is need to always confirm the source of information (social media accounts often try to appear as if they are from legitimate news sites), check different sources to confirm the authentication of the information you are reading. There is need to always penalize those blogs or media outlets that post fake news no matter the circumstance. By so doing, it will serve as deterrent to others using it as a way to gain relevance or for whatever reason.
\end{abstract}

Keywords: Fake News, Causes, Effects, Management, Nigeria

DOI: $10.7176 / \mathrm{IKM} / 9-2-10$

\section{Introduction}

Fake news is a neologism often used to refer to fabricated news. This type of news, found in traditional news, social media or fake news websites, has no basis, but is presented as being factually accurate (Wikipedia, n.d). Claire Wardle of First Draft News identifies seven types of fake news; Satire or parody (no intention to cause harm but has potential to fool), false connection (when headlines, visuals or captions don't support the content), misleading content (misleading use of information to frame an issue or an individual), false context (when genuine content is shared with false contextual information), imposter content (when genuine sources are impersonated with false, made-up sources), manipulated content (when genuine information or imagery is manipulated to deceive, as with a doctored photo) and fabricated content (new content is $100 \%$ false, designed to deceive and do harm) (Wikipedia, n.d).

Fake news is a global issue right now; there is an ongoing discussion about fake news and its impact on global affairs. There are several reports that Russia planted fake news stories to influence the outcome of the United States elections. Also, social media was abuzz with certain 'Pizzagate' scandal- a news story claiming Hillary Clinton and her campaign chairman John Podesta were the ringleaders of a pedophilia ring running out of Washington DC. The story was proven fake when The New York Times and the Washington Post tracked it down and debunked it (Adeleke, 2016). One of the main subjects of attack of the fake news phenomenon is Facebook, the world's largest social network with a monthly active user base of 1.7 billion, more than the population of China and the United States combined. The platform has been used to peddle all kinds of news stories, all in a bid for platforms to rake in advertising revenue. For long, Facebook (or rather Mark Zuckerberg) denied its fake news problem. However, after a lot of pressure, it finally to do something about it by introducing a fake news signal that makes it easy for users to report and identify fake news. The flagged fake news will then be reviewed by Facebook's fact checkers, an army of third party journalists from media organizations (Adeleke, 2016).

The spread of the fake news phenomenon on the internet is caused by the internet's ever connected nature and the preference for speed over accuracy. Because internet content providers and distributors are in Zero-sum, winner-takes-all battle for attention and advertising revenue, they will do any and everything to boost traffic. Unlike print publications that usually have the luxury of time before reporting a breaking story the next day, online publications are necessitated by the franticness of the world in which they find themselves. On the internet, you either go fast or go home. Many journalists, because they are competing for attention and mindshare, are forced to publish first and verify later, and this is what is hurting our world (Adeleke, 2016). However, Nigeria has this problem too but there's not a lot of discussion going on about it. New sites and blogs publish stories without first authenticating the sources. Fake news stories are usually sensational in nature and so are very likely to spread quickly. And because the platforms containing the news already have a massive reader base that looks to them for information, the stories will most likely be believed by the people that read them. 
These people will, in turn, share the story on social media (because who doesn't like to pride themselves on being one of the first to know), and the show, sadly, goes on and on. Sometimes, even after the story has been debunked, the fake news still prevails (Adeleke, 2016).

Furthermore, as regards to fake news the Federal Government in Abuja launched a national campaign against fake news. According to the Minister of Information and Culture, Alhaji Lai Mohammed at the formal launching of the campaign stated that fake news was becoming a serious threat to global peace, including Nigeria, that if left unchecked, could endanger human existence. The minister, who also described fake news as a dangerous threat to democracy, noted that fake news when mixed with hate speech would amount to a disaster waiting to happen (Elebeke, 2018).

On the impact of fake news, the Minister of Information and Culture said 'the global epidemic of fake news is already having far reaching repercussions across the world. A recent study by researchers at Ohio State University in the United States concluded that Russian interference and the fake news it promoted probably played a significant role in depressing Hilary Clinton's support on Election Day during the 2016 presidential elections in the United States. Among the Fake News circulated ahead of the election were: Clinton is in poor health due to a serious disease; Pope Francis endorsed candidate Trump; Clinton approved weapons sales to Islamic Jihadists etc.

In India, about a dozen people have been killed just because of fake news of hoax messages (Elebeke, 2018). The victims were lynched after they were falsely accused of child abduction based on fake messages circulated via the social media platform, WhatsApp.

Right here in Nigeria, the situation is not better. It is not restricted to the social media. On $5^{\text {th }} \mathrm{July}$, 2018, the front page headline of a national newspaper was: Court orders National Assembly to begin impeachment of Buhari. The problem with that news item is that it is fake news. According to the certified true copy of the order, the Presiding Judge of the Federal High Court in Oshogbo ordered and I quote: "The applicants are hereby granted leave to issue and bring an Application for the order of Mandamus to compel $1^{\text {st }}$ to $3^{\text {rd }}$ Respondents to start impeachment proceedings against the $4^{\text {th }}$ Respondent, the president of the Federal Republic of Nigeria. This was manipulated to read that the court has given the go-ahead for the National Assembly to commence impeachment proceedings against the President. In 2017, a fake report circulated on the social media claimed that five students of the College of Education, Gidan Waya, were ambushed and killed by Fulani herdsmen in Southern Kaduna. That report turned out to be false. No student was killed. I can go on and on (Elebeke, 2018).

Finally, the essence of the campaign is to sensitize all Nigerians to the dangers posed to the peace and security, and indeed the corporate existence of Nigeria by the phenomenon, and the fact that each and every Nigerian has a role to play in curtailing the spread of fake news. Also, the study looked at impact of fake news in Nigeria, the likely causes, the effects and possible ways to reduce it to insignificant level.

\section{Causes of Fake News}

Below are the major causes of fake news in Nigeria and the world at large.

- $\quad$ Relevance: For media outlets, the ability to attract viewers to their websites is by publishing a story with false content which benefits advertisers and improves ratings.

- Hostile government and civil actors have also been implicated in generating and propagating fake news, particularly during elections (Wikipedia, n.d).

- Money making: Jestin Coler, former CEO of the fake media conglomerate Disinfomedia, said that his

company employed 20 to 25 writers at a time and made $\$ 10,000$ to $\$ 30,000$ monthly from advertisements

(Wikipedia, n.d). This is not far from fake Nigerian media outlet.

- $\quad$ Poor regulation of the internet: The internet was first made accessible for public use in the 1990s, its

main purpose was for the seeking and accessing of information. As fake news was introduced to the internet, this made it difficult for some people to find truthful information. The impact of fake news has become a worldwide phenomenon. Fake news is often spread through the use of fake news websites, which, in order to gain credibility, specialize in creating attention-grabbing news, which often impersonate well-known news sources (Wikipedia, n.d).

-

\section{Effects of Fake News in Nigeria}

Fake news aggravates herders/farmers crises in Nigeria: The British Broadcasting Corporation (BBC) has reported that fake news circulating in the social media is fueling the farmers/ herdsmen crises in Nigeria. In the report by the media organization, it stated that "fake pictures circulating on social media which users are falsely claiming depict inter-communal violence are inflaming already high tensions in Nigeria" (Adekunle, 
2018). The international media outfit, specifically made reference to repellent images circulating in the social media which the originators purportedly claimed was from recent violence in Jos, Plateau State. A gruesome image of a woman faces down in a pool of blood with a gaping shoulder wound is purported to be from the recent attacks. It has hundreds of retweets on Twitter, but it first appeared on the internet in 2011 in a story about domestic violence in Nigeria. Another image appears to show half a dozen people that were killed in the attacks. On closer inspection it becomes clear that the picture was not taken in Nigeria, and is actually the scene of a 2015 traffic accident in the Dominican Republic (Adekunle, 2018).

Also, major Nigerian news outlets ran a story claiming that Danladi Ciroma, a leader of the Miyetti Allah Cattle Breeders Association, said the attacks in Plateau were revenge for the loss of 300 cows. "Since, these cows were not found, no-one should expect peace in the areas", Mr Ciroma was reported to have said. Ciroma had refuted the report and the media organization had reportedly tendered apology (Adekunle, 2018).

Fake news most times instigates confusion, tension, suicide depending on the person or institution on the other end and it undermines serious media coverage and makes it more difficult for journalists to cover significant news stories (Wikipedia, n.d).

\section{Management of Fake News}

Brian Hughes, a professor of media studies at Queens College, City University of New York, writes that "it would be a mistake to pressure Facebook and Google into acting as censors" for news because, "we have already seen how much such an approach can backfire". He cites the example of Facebook's manipulation of its trending newsfeed to suppress conservative news. This, he says, only increases public distrust for the media, turning them to less credible news sources instead. Professor Hughes says we should consider the possibility of adopting the Fairness Doctrine for digital media. He says it should be possible for companies like Facebook to 'individually program our news feeds for balance and accuracy' 'since they are already able to identify consumer niches (Adeleke, 2016).

Nicholas Lemann of the New Yorker argues for more government involvement as a way of solving this problem. He says that 'it's facile and unhelpful to assume that government's role in journalism can be either nothing or absolute control for propaganda purposes". He proposes that the government invest more in the pubic media to give more room for press freedom and journalistic integrity. But i wonder how effective this will be if we try to adopt it to Nigeria, considering the country's political climate, one where the government is viewed as corrupt and untrustworthy.

We cannot eliminate fake news. As long as there are people willing to buy tabloids and read blogs that they already know contain lies and half-truths, and as long as we have uneducated people who are unable to differentiate between real and fake news, fake news will continue to sell. The solution to the fake news problem lies in the online media revenue model. Articles online are optimized for clicks. That means that the best performing content-headline, article body, the images etc- are designed, wittingly or unwittingly, to get people to click on them. The more clicks and the more time spent on an article, the better the analytics figure, the more likely the media house is to attract premium advertising revenue. So, to get from the point of content to more revenue, many times media platforms water down journalistic standards and integrity. Online media is a zerosum game: the more time someone spends on your platform, the more time they spend way from other platforms (Adeleke, 2016).

The Minister stated that big technology companies like Google, Facebook and Twitter have started to address the problem. Google is reported to have dedicated 300 million US dollars over the next three years towards efforts to fight the spread of false information. Facebook, according to Bloomberg, took down 583 million fake accounts in the first three months of 2018. According to Reuters, Twitter suspended over 70 million accounts in May and June this year alone, and the pace of suspension has continued. Apart from the big technological organizations, the European Commission, in January 2018, set up a high-level group of experts to advice on policy initiatives to counter fake news and disinformation spread online (Elebeke, 2018).

According to Jamie Angus, the Director of BBC World Service Group encouraged people to fall back on the most trusted news brands they could rely on for their news sources. He also advocated increased standard of education and media literacy. He went further to say that there is need to educate the young people in particular on what is trustworthy and what is fake. Media literacy is key in this regard. It is also important for people to invest more in making journalists to partner with reputable and credible international media organizations. Again, government must find ways to support its core traditional media for acceptability over the social media. Finally, Nigeria must find a way to ensure that its national newspapers and TV stations are sustainable to practice quality journalism that will be acceptable to people. When you do that successfully, you will consider good independent regulation of the media; with this will reduce the attention that the fake media get and penalty should be given for maliciously published items (Okogba, 2018). 


\section{Methodology}

This study which centered on Fake News in Nigeria: Causes, Effects and its Management relied on secondary source of data collection. The research design used in this work was documentary.

Secondary sources of data collection are published and unpublished materials, books and Newspapers relevant to this study.

\section{Findings}

It was discovered that in Nigeria and the world at large, most people don't always confirm the source of information before believing and sharing the information which most times turn out to be fake. It was discovered that fake news generated online and offline most times are to create traffic and relevance.

It was also discovered that there is a lacuna between the government and media (Online and Offline) in areas of monitoring and supervision as a result of that bad elements uses that to cause tension.

We also found out that there is no full press freedom and journalistic integrity which goes a long way to create room for fabrication of fake news.

\section{Recommendations}

There is need to always confirm the source of information (social media accounts often try to appear as if they are from legitimate news sites), check different sources to confirm the authentication of the information you are reading. Also, engage different verification tools online like Tin Eye, Google and Bing which can tell what you need to know about information you came across. Again, there is need to engage Metadata (a tool); it will tell you where and when an image or video was captured to avoid confusion in the case of fake news. After that, then think before you post/share is very important.

There is need to always penalize those blogs or media outlets that post fake news no matter the circumstance. By so doing, it will serve as a deterrent to others using it as a way to gain relevance or with other reasons too.

There is need for the government to work with the media and invest also to avoid creating room for fake news. Also, the government should give room for full press freedom and journalistic integrity in Nigeria and the world at large.

\section{Conclusion}

In summary, we can say that fake news is not peculiar to Nigeria alone, it is a global problem which has done more harm than good in our society. We are of the opinion that the government at all levels should work aggressively and assiduously with the media towards ensuring that the rate at which fake news grow are minimized to an insignificant level to avoid further tensions, killings and so on. The government should do more on media literacy and promote some reliable media outlets the people can always fall back on for information. If all these mentioned above can be achieved then the world will be a better place.

\section{References}

Adekunle (2018). Fake news aggravating herders/farmers crises in Nigeria-BBC. Vanguardngr.com, [Online] Available: https:// www.google.com/amp/s/www.vanguardngr.com/2018/06/fake-news-aggravating-herdersfarmers-crises-nigeria-bbc (June 30th , 2018)

Adeleke, I. D. (2016). Nigeria has always had a fake news problem, but why have we decided not to talk about it?. Ventureafrica.com, [Online] Available: https://www.google.com/amp/venturesafrica.com/nigeria-fakenews-problem/amp (December 17, 2016).

Elebeke E. (2018). Federal Government launches campaign against fake news. Vanguard [Online] Available: https://www.google.com/amp/s/www.vanguardngrcom/2018/07/fg-launches-campaign-against-fake-news/amp/ (July 12, 2018).

Okogba, E. (2018). 2019 polls: BBC raises concerns over fake news. Vanguardngr, [Online] Available:https://www.google.com/amp/s/www.vanguardngr.com/2018/07/2019- polls-bbc-raisesconcerns-fake-news/amp/ (July 2nd, 2018)

Wikipedia (n.d). Fake news. Available: https://en.m.wikipedia.org/wiki/fake_newsHYPERLINK "https://en.m.wikipedia.org/wiki/fake_news\%26hl-en-NG"\&HYPERLINK

"https://en.m.wikipedia.org/wiki/fake_news\%26hl-en-NG"hlHYPERLINK

"https://en.m.wikipedia.org/wiki/fake_news\%26hl-en-NG"-HYPERLINK

"https://en.m.wikipedia.org/wiki/fake_news\%26hl-en-NG"enHYPERLINK

"https://en.m.wikipedia.org/wiki/fake_news\%26hl-en-NG"-HYPERLINK

"https://en.m.wikipedia.org/wiki/fake_news\%26hl-en-NG"NGHYPERLINK

"https://en.m.wikipedia.org/wiki/fake_news\%26hl-en-NG". Accessed Date:

25/7/2018 